\title{
Disruption and Collaboration in Digital Journalism: Ambivalence of Social Responsibility and Political Economy Practices of Media Companies
}

\author{
MUFTI NURLATIFAH \\ NINA MUTMAINNAH \\ Universitas Indonesia
}

\begin{abstract}
Digitization encourages journalism to transform. Since the development of digital media, communication and media scholars have predicted journalism to develop at two levels. First, journalism evolves along with technological developments and is involved in media disruption. Second, journalism sticks with professionalism and establish technology as a tool to realize social responsibility. Today we are dealing with the transformation in journalism that we get from disrupted contents, disrupted media companies, and collaboration among media institutions. Various digital journalism platforms have emerged as a manifestation of the diversity of content and diversity of media ownership. This was an exploratory study that aimed to explain collaborations among various media in the digital ecosystem. The focus of this study was to map media networks through media data distributed in various official media or regulators. The results of this study showed that in a digital ecosystem that promises many opportunities, digital journalism still has to deal with the dilemma between social responsibility and the political economy of media. On the one hand, digital journalism faces disruption which serves as a significant factor that encourages journalism to transform. On the other hand, digital journalism also deals with a natural selection that forces them to collaborate, i.e. a manifestation of the political economy of media.
\end{abstract}

Keywords: Digital journalism, disruption, collaboration, social responsibility, media companies.

\section{INTRODUCTION}

The existence of digital media has brought challenges for journalism as an ecosystem to produce and distribute information. Many researchers on journalism are aware of the fact that the development of journalism is inseparable from technological developments, so digital journalism is considered an unavoidable necessity. Various opportunities for production and information have emerged along with the development of digital journalism (Hermida, 2010; Peter a\& Broersma, 2013). Nevertheless, several statements are saying that digitization has killed "the spirit of journalism" (Waishbord, 2001; Anderson, 2012; Deuze \& Witschge, 2018).

In the middle of adaptation carried out by newsroom-based journalism, the media industry also experiences changes because digital media has disrupted various media lines. The challenges faced by digital media platforms consist of several crucial issues, namely: managing media companies to become a trusted source of information; earning revenue to keep carrying out journalism activities; and searching for digital distribution strategies to effectively reach the public and their stakeholders (Wikstrom \& Ellonen, 2012; Evens et al., 2017). Changes in the readers' behaviour patterns and the demands of the media business dynamics have put the media industry in a dilemmatic pressure between journalistic idealism and market flow. The most significant aspect perceived by the media industry is the emergence of free contents through various digital media platforms amid the inability of the news business to generate a decent income from the online activities they are involved in 
(Herbert \& Thurman, 2007; Chyi, 2005; Casero-Ripolles \& Izquierdo-Castillo, 2013). Unfortunately, quite promising audience growth and audiences' high demand do not necessarily bring benefits to the media industry.

Various business models for the media industry are then developed to balance the high needs for information and the needs of the media companies to earn profits. According to Casero-Ripollers (2010), there are five types of business models adapted by online media platforms today. First, free content/advertiser-supported. This is the most common model adapted by online media platforms today by placing advertisers as the only source of income. Second, pay-wall or paid based on accessibility using certain criteria. This model is based on subscription for a certain number of accesses, of which the calculation is either based on duration such as weekly, monthly, or annually or based on the number of articles being accessed or the number of contents. Third, a metered model which is based on the amount of access. This model attracts users by providing a minimum amount of access to media contents. For example, free for the first ten contents, followed by paid contents. Fourth, freemium. This model combines a free access model with paid contents at the end. This means that not all the contents can be accessed, but only partially. If users want full access, then they have to make payments. Fifth, donation. This makes use of voluntary contribution from the audiences accessing their media platforms. This model is the most rarely found in the digital media industry today (McChesney \& Nichols, 2010).

Based on these opinions, this paper tries to present a deeper exploration of the efforts of various digital journalism platforms in Indonesia to survive amid the current digital media competition. The assumptions used in this study were built through two main points. First, the digital media ecosystem has forced journalism to change, either in the context of newsrooms or in its media business model. As a consequence, there is a conflicting interest between journalistic idealism and market demands which serve as the foundation for digital journalism to survive and exist. In this context, impartiality is faced with an objectivity which is at the heart of journalism dynamics.

Second, the development of digital journalism nowadays has forced various media companies to make collaborate to survive amid the hustle and bustle of the media industry competition. In the end, this effort becomes a contradiction between the efforts to maintain their idealism with the effort to develop a new model to flow with the political economy of media due to digitization. The next question is: what is the responsibility of digital journalism actors if the important consideration is how to survive. The disruption of digital media has eventually become a significant and unavoidable factor because it changes and forces journalism to change.

\section{LITERATURE REVIEW}

The presence of the internet as a digital media is believed to be a marker of the era, where a revolution in goods and services takes place, strengthens and empowers the community (Gingrich, 1995). One factor that makes digitization interesting to be brought up as a discussion topic in media studies is its transformation in shaping the character of communication and a new kind of society. The social context in new media transformation is seen as a major implication of the emergence of digital media on the relationship between humans, the relationship between human and the environment, differences that emerge between groups and social sectors, and various social phenomena that depict the restructuring of social relations (Murdock \& Golding, 2002). Eventually, contradictions 
emerge from the transformation of digital media in the context of media and society (Golding, 1996) or digital dilemma.

First, the dilemma in terms of community use and market mechanism (Bustamante, 2004; Lindgren, 2017; Maryani et al., 2020). Information is an important commodity both from a social and economic perspective. In the social context, information is ammunition to create a cohesive society. Meanwhile, in the economic context, information is a commodity that contains economic values. The two sides of information amid the development of digital media have encouraged a massive increase in efficiency to improve the welfare of life. Information has become a commodity distributed with the lowest possible cost to produce cohesiveness in a wider community. This is the standard used by the information industry in digital media, "the industry believes that in the long run, this other set of services will prove more lucrative," (Besser, 1995, hlm. 64).

Second, the dilemma between integration and exclusion in digital media. Media convergence has promised the integration of messages and cultures, where horizontal communication takes place in a community with uniform tools and information (Golding, 1996). On the other hand, however, this convergence also raises exclusion and differences in society. Negroponte (1996) suspected this as a trigger for the digital divide. Digital nativedigital immigrant, babyboomers-Millenials, and Millenials-generation alpha are several dichotomies that seek to explain how different accessibility of information and media by the community serves as an indicator of the digital divide. This also indicates that the differences in the community's engagement and accessibility to digital media serve as a necessity in media transformation.

Third, the dilemma between diversity and the possibility of media conglomeration (Golding, 1996, Tapsell, 2015). Digital media encourages diversity of contents and diversity of ownership to be implemented through the contents and organizations of media. At the same time, this condition also raises a dilemma over the emergence of ethical consequences and the practices of the political economy of media. In digital media, there is no clear boundary between producers and consumers. Meanwhile, instead of bringing more benefits to the use of communication technology, content distributors in digital media prefer to develop technology-based economic activities (Golding, 1996). This means that the emergence of media convergence still provides legitimacy to the development of capitalism since technology is only placed as a means of marketing and promoting certain brands. This is then referred to as media monetization.

The digital dilemma also emerges in the context of digital journalism. Journalism digitization emerges not only as a logical consequence of the development of communication technology but also as an aspect of the transformation of content and media management. Pavlik (2001) described that digital media has brought changes in journalism on four sides (Pavlik, 2001). First, journalism transformation due to digital media is manifested as a change in media contents as a result of technological convergence. Digital journalism contents emerge as dynamic texts, where contents are understood not only as a mere static media text but also in terms of the convergence with other texts, or is known as hypertextuality.

Second, the transformation of journalists in presenting the information. The development of digital contents has forced journalists to negotiate with various technological disruptions (Wunsh-Vincent, 2017). As the most affected party by the development of new media, journalists cannot help but expand to survive. The demand for journalists in digital media is no longer only in their ability to write news. They are also encouraged to present 
information comprehensively, involving technical skills apart from writing, including how to record images, edit images, display graphics, and process data. These transformation and adaptation are also known as remediation (Bolter \& Grusin, 1999; Omar, 2017).

Third, newsroom dynamics and transformation. Newsroom is no longer understood as a mere conventional room, but also a virtual one. Networking in new media not only allows for a newsroom to emerge anywhere but in the context of digital media, it can also involve anyone. The processes of selection and representation of information into texts in digital journalism are not only about formal structures (Shoemaker \& Reese, 2014; Schudson, 2001). The decision to publish and disseminate news to the public in the context of digital organizations involves not only humans but also data and machines. Gatekeeping in digital journalism also considers technological factors as a determinant in newsroom policy.

Fourth, the transformation of media-public relations. The power of networks in digital media has changed the network of media maps: from a mere dichotomy between the media as producers and the public as consumers, this relation has developed into a wider network than such dichotomy. In the context of public relations, the elements of creating media contents in digital media also involve the public as an entity, for example, user-generated contents.

The transformation of journalism has affected and disrupted various sectors of the media industry in which journalism still serves as its main activity. The disruption in media companies takes place in four main domains in the digital journalism ecosystem, namely the structure of media companies, the habits of consumers who consume information from the media, professional journalism practices, and changes in the media business model that is developing (Garcia-Aviles et al., 2018). This indicates the presence of catastrophe and the rebirth of media companies where journalism works in the digital ecosystem (Anderson, Bell, \& Shirky, 2012). It is considered a catastrophe because, to survive, journalism has to adapt to various changes quickly. Meanwhile, journalism is said to be reborn because all the media companies that still uphold their journalistic idealism have to make innovations to generate "new good" and "new quality of good", new methods for producing information, new markets that consume the information, new sources that will always provide information, and new structures that become the drivers of the companies (Anthony, 2012; Garcia-Aviles et al., 2018).

Innovations in the media industry are not only a novelty offered by the media. Innovations also require solid media management and integration between human and the resources of changes in the industry (Boczkowski, 2004). That is, innovations are not only a demand from the transforming media, but also an awareness to relate people, technology, media companies, and communication within the companies (Garcia-Aviles, 2018). Such relation is what later determines the typology of the innovations based on the transformation that takes place.

\section{METHODOLOGY}

The research method used in this study was a desk study. It was carried out by developing secondary data spread through digital media (Alasuutari et al., 2008; Gibbs, 2007). Before the data analysis process, these approaches were built in three major phases of the study. The first stages used the distribution of big data in various digital pages as the main database (Sloan \& Quan-Haase, 2017). The first stage was to conduct data crawling of companies listed on the official website of the Press Council. The second stage was to search for additional data 
through the media profiles that were found on the pages of each media. There were four main data highlighted in the second stage, namely: a general description of the media including the official name used by the media company; the organizational structure of the media and the names of the media officials; the media network with a larger corporation or with the same media network; and the media affiliations or media managers with larger power structures. The third stage was to conduct data analysis through categorization and cross-tabulation. The results of the data collection in the first and second stages were then sorted using Microsoft Excel to see the distribution and identity of the media. The results of the cross-tabulation were used to examine the maps established from the collaboration among media in the digital journalism ecosystem in Indonesia.

The focus of this research was a media organization network. The objectives of this research were to get comprehensive data on the profile of media and criticize the media networks established from the network of digital media companies. The paradigm used in this research was a critical paradigm by outlining various power relations and ideologies (Wimmer \& Dominick, 2010) developed through collaborative networks in digital journalism companies. The researchers assumed that the network established by various media companies in this study was not a mere relation among media companies, but an effort of media negotiation to gain power and create hegemony for the public.

\section{RESULTS AND DISCUSSION}

Based on the data uploaded in the archives of the Press Council until the end of 2018, there were 958 digital journalism platforms registered in the Press Council. From all the 34 provinces in Indonesia, each province is represented by media companies located in the province. Referring to such a total number, the community's needs for information should ideally be met. Quantitatively, this number justifies the distribution of information in Indonesia through digital media platforms. It is necessary to elaborate the justification to deepen the diversity aspect through the diversity of contents and diversity of ownership of the media platforms.

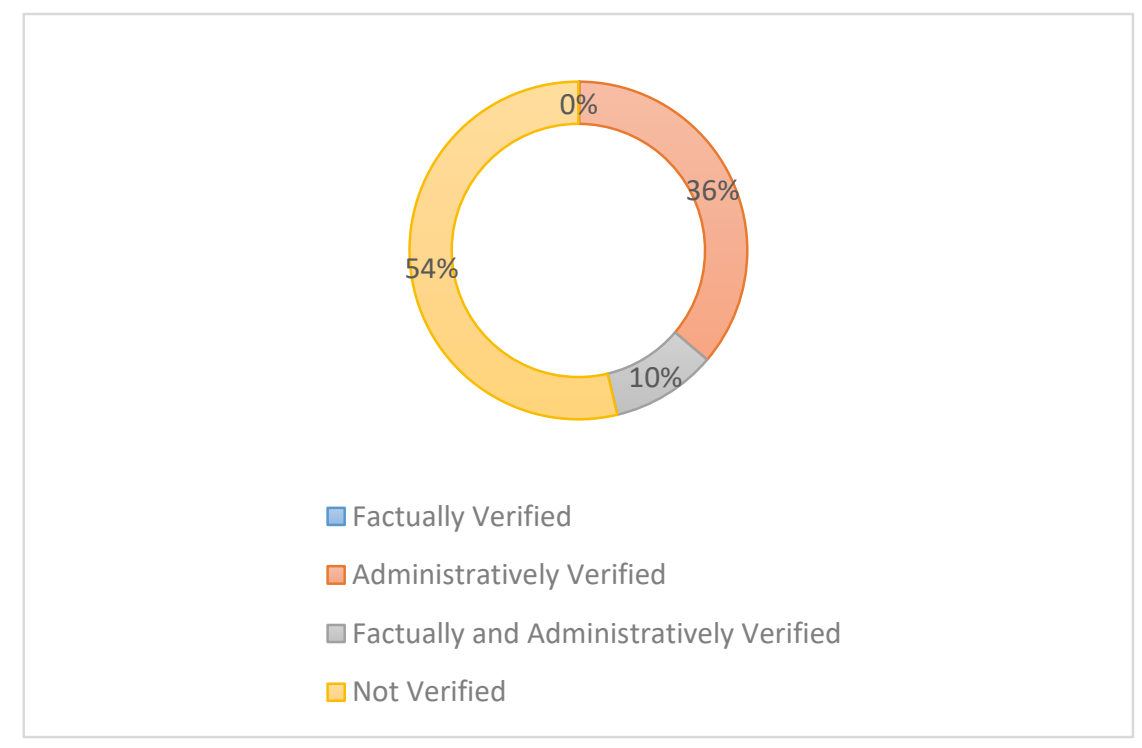

Figure 1: Data of Media Companies Registered in the Press Council 
From the total number of media in Indonesia, most of these media are located in Riau Province (12\%), followed by Jakarta (11\%) and East Java $(9.7 \%)$. This finding is quite interesting as a counter to the existing general assumption that the majority of the media were located in Java, particularly in the capital city of the country i.e. Jakarta. On the other hand, North Kalimantan province has the lowest number of media, i.e. only 6 media or around $0.2 \%$ of all the media throughout Indonesia are located in North Kalimantan. In general, each region has a media that represents the uniqueness and diversity of each of these regions. Although these local media still bring up some national issues, local representation has also started to be brought up in these media, as seen in the following reports:

Table 1: News on Local Digital Media Platforms

\begin{tabular}{lcc}
\hline \multicolumn{1}{c}{ Riaumandiri.com } & Sulutdaily.com & Harianhaluan.com \\
\hline $\begin{array}{l}\text { Kampar Berduka, Bupati Azis Zaenal Meninggal } \\
\text { Dunia }\end{array}$ & $\begin{array}{c}\text { Tradisi Bendi Natal Warnai Woloan TomBar } \\
\text { Mentawai Butuh Lapas }\end{array}$ \\
\hline
\end{tabular}

In this context, the presence of local media platforms in all regions provides more rooms for a local news broadcast. This could minimize the Jakarta-centered or national news reporting, thus serving as a manifestation of diversity of contents. With an increasing number of digital media, diversity of ownership hopefully will also emerge. However, ownership centred on several parties is still an unavoidable classic issue, including in digital media platforms.

\section{Collaborative Network Categorization}

Based on the categorization of media companies and media ownership, there are generally three categories of digital journalism collaborations identified in the digital journalism ecosystem in Indonesia. These three categories reflect the distribution of digital media ownership in Indonesia. First, the holding company of large national media companies, including print media, broadcast media, and online media which expand their business and perform media spatialization. Second, new players of online media companies including local entrepreneurs, media professionals and corporate local networks. Third, the collaboration category where the media is not a collaboration company of some companies or media companies that are under a particular media network.

The first category is holding company of large companies which already become the players in conventional media such as print and broadcast media that expand their business into digital platforms. Nonetheless, there are also some holding companies which concentrate their business on digital media as their main platforms since the very beginning. Some holding companies that fall into this category include: 
Table 2: Top Digital Media Companies in Indonesia

\begin{tabular}{ll}
\hline \multicolumn{1}{c}{ Companies } & \multicolumn{1}{c}{ Digital Media Platforms } \\
\hline EMTEK & Liputan6.com; Vidio.com; Bola.com; Bintang.com; Oto.com; Kapanlagi.com; \\
& Merdeka.com; Vemale.com; Otosia.com; Fimela.com; Sooperboy.com' \\
& Techno.id; Muvila.com; Brilio.net; Dream.co.id; Famous.id; Feed.id. \\
& Bisnis Indonesia; Kabar24; Solopos; Nikkan Business Line; Solopos FM; \\
& Harianjogja; Star Jogja FM; Madiun Pos; Semarang Pos; and Rumah 190. \\
& The best thing about MNC is that its broadcast networks cover four frequency \\
MNC & channels, namely RCTI, MNCTV, GTV, and news. Also, online media networks \\
& under MNC are Okezone.com; inews.id; and sindonews.com. \\
& All the companies under Jawa Pos. In addition, this network is also built on local \\
JPNN & online pages, such as: Pojok Jabar; Pojok Sulsel; Pojok Bandung; Pojok Sumut; \\
& Go Bekasi; Pojok Jogja; and Metropolitan.id \\
& Networks under PT Tribun Digital Online, Divisi Koran Daerah Kompas Gramedia \\
TRIBUN & (Group of Regional Newspaper) or Tribun networks. \\
KOMPAS GRAMEDIA & In addition to Kompas.com and Kompas.id, digital media platforms managed by \\
& Kompas Gramedia are Grid.id; BolaSport.com; Cewekbanget.id; Fotokita; \\
& Gridoto.com; Hai; Intisari; National Geographic Indonesia; Nextren; Otomania; \\
& Otomotifnet; Sajian Sedap; Stylo.id; Nakita.ud; and Nova.id. \\
\hline
\end{tabular}

The majority of the abovementioned large media companies are national companies that have long been in the media business. The presence of digital media in each of these companies indicates the expansion of the companies to other media platforms, instead of showing the companies' efforts to build deliberation of information networks among the community. Digitization offers companies more opportunities because technology can deliver messages quickly, thus providing opportunities for companies to create domination on a larger scope. For these companies, digital media have more functions for product differentiation (Biagi, 2016) rather than information differentiation. This is a practice of spatialization, where media serve as an expansion of media companies manifested in the form of corporations and the extent of the media business (Mosco, 2009).

The second category is new players in digital media, ranging from start-up media companies, non-media entrepreneurs who expand to the media business, to the development of new digital media genres. The media companies, newly emerging to fill the digital journalism ecosystem in Indonesia, develop by looking at the differentiation of digital products using journalistic standards. The contents they produce are posted on different pages although they are actually under the same company. Several new players who fill the digital journalism include:

Table 3: New Players in Digital Journalism in Indonesia

\begin{tabular}{|c|c|c|}
\hline Companies & Digital Media Platforms & Media Description \\
\hline IDN MEDIA & $\begin{array}{l}\text { IDN Times, Popbela, Popmama, and } \\
\text { Yummy }\end{array}$ & $\begin{array}{l}\text { Digital media platforms present information for } \\
\text { the millennials and generation } Z \text {. The } \\
\text { segmentation of Popbela is fashion and lifestyle } \\
\text { contents. Meanwhile, Popmama presents worth } \\
\text { sharing contents for millennial moms in } \\
\text { Indonesia. }\end{array}$ \\
\hline BASKO MEDIA & Basko manages Haluan Media & The media managed by Basko Media Group \\
\hline GROUP & $\begin{array}{l}\text { Group which consists of Harian } \\
\text { Haluan Padang, Riau Mandiri, and } \\
\text { Harian Haluan Kepri }\end{array}$ & $\begin{array}{l}\text { under the umbrella of Haluan Media Group are: } \\
\text { first, Haluan Padang which was launched in } \\
\text { 2010, followed by Riau Mandiri and Harian } \\
\text { Haluan Kepri. }\end{array}$ \\
\hline
\end{tabular}




\begin{tabular}{lll}
\hline AYO MEDIA & Ayo Network consists of several & Ayo Media Network is located in several cities in \\
NETWORK & $\begin{array}{l}\text { media, namely: ayobandung.com; } \\
\text { ayobekasi.net; ayobogor.com; }\end{array}$ & $\begin{array}{l}\text { Indonesia. Ayo Media is not only a media } \\
\text { network, but also a social media analyst, digital } \\
\text { ayocirebon.com; }\end{array}$ \\
& $\begin{array}{l}\text { monitoring, buzzer management, search engine } \\
\text { ayopurwakarta.com; aytasik.com; } \\
\text { ayosemarang.com; and } \\
\text { ayoyogya.com }\end{array}$ & $\begin{array}{l}\text { optimization, native advertising agency, and } \\
\text { public relation support. }\end{array}$ \\
\hline
\end{tabular}

IDN Media and Ayo Media Network are categorized as new players in the digital media industry. These two media are not the result of an expansion of conventional media. Instead, they are new players who develop a digital media ecosystem by offering a variety of media contents. IDN Media was founded by Winston Utomo and William Utomo in 2014 after Winston Utama left Google. They adapted Buzzfeed to develop IDN media by targeting the millennials and generation $Z$ as the audiences. On the other hand, Ayo Media Network is not fully a media company. Ayo Media Network is an agency that prepares itself to develop digital media ecosystems, including the digital journalism ecosystem. The digital journalism ecosystem at the local level is managed by those who create contents in their regions. Being integrated into a shared network, the digital media platforms complete each other and make collaborations to provide important information related to their regions.

Being different, Basko Media Group falls in the second category, i.e. new players, not because it is a new media company like IDN Media and Ayo Media Network. Before expanding to a digital platform, Basko Media Group was a Harian Haluan newspaper in West Sumatera. After acquired by Basko Media Group, the Harian Haluan newspaper was transformed into an online platform to broadcast regional information. This media covers not only West Sumatera because the ownership of Basko Media Group also covers Riau Mandiri and the Harian Haluan Kepri. In addition to being a media company, Basko as a local entrepreneur also manages several non-media companies such as property, malls, hotels and mining. The media line is the last line developed by and under the ownership of Basko after he realized that media has a significant effect to develop his image before the public (Yusuf, 2009).

The third collaboration category is a collaboration involving media that are not always from the same media company. The collaborations in this category are more diverse because they involve international companies. Two networks that can be used as an example for this category are Tirto.id with Facebook and Kabar News Network. These two networks depict the relation between media companies with other companies, either media or non-media companies.

The first network is a network established between Tirto and Facebook. Tirto is one of the digital media platforms in Indonesia. Since its establishment, Tirto has developed investigative journalism patterns which not only report field findings but also report various phenomena based on comprehensive data. This pattern is said to be precision journalism.

At the beginning of 2018, Tirto was invited by Facebook as a third-party factchecker to verify hoax, misinformation, and disinformation circulating through various digital contents. Also, Tirto has the opportunity to utilize various digital devices developed by Facebook in verifying data and information. The collaboration between Tirto and Facebook is manifested in the rubric 'Check Data', which was then changed into 'Check Facts'. This rubric presents some writings containing the analysis results of various phenomena that require research and data verification. 
The collaboration method developed by Tirto and Facebook is not only a gatheringdata collaboration to present information. Further, Tirto even develops it into one genre of digital journalism that still exists today, namely fact-checking journalism. Fact-Checking Journalism, in the context of digital journalism practise, is carried out using a narrative method similar to other digital journalism in general. However, fact-checking journalism emphasizes "reported speech" rather than "reporter get a quote right" (Amazeen, 2017). A reporter's narratives in presenting news are the main focus for it serves as a narrator, instead of serving as a quote collector who is biased with a certain framing. In general, the characteristics of fact-checking journalism are hypertextuality, interactivity, non-linearity, multimedia, convergence, and personality (Kawamoto, 2003; Pavlik 2008). Similar to other digital journalism contents, audiences will also still find narrative texts in fact-checking journalism. The difference is, the body of the narrations contains a hyperlink that will bring the audience to the sources referred to by the journalist when writing the news.

The main objective of fact-checking journalism is to educate the public, improve political behaviour, and improve the quality of journalism (Amazeen, 2017). In the collaboration between Tirto and Facebook, the media involves audiences (Tirto users) to trace the sources or origins of information and how the information develops. This type of journalism is not only a collaboration between Tirto as a media company and Facebook as a technology company but also a collaboration with the public as the audiences to participate in concluding.

The second network established in the digital media platform is the one established in the Kabar News Network group. Kabar News Network is a network of local online media companies in Indonesia. Some of the media joining the Kabar News Network are Kabar Medan, Kabar Papua, Kabar Sumbar, Kabar Padang, Kabar Nusa, and Kabar Sumatera. Although the Kabar News Network is interconnected, each of these media has their media management. For examples, the Editor in Chief of Kabar Medan is Agoez Perdana, while the Editor in Chief of Kabar Papua is Syamsuddin Levi Lazore. The network established by Kabar News Network is a form of news syndication found in the digital journalism practice in Indonesia.

Syndication is an online journalism practice that is frequently defined as the practice of media content reproduction using other media content sources in a particular connection (Bruhn, 2004). Some online media perform this by building a network, which is not mentioned in the media management such as Kabar News Network. On the other hand, some other media mention it, for example, www.teraslampung.com. This media discloses the digital journalism platforms that serve as its news syndication including tabloidjubi.com (Papua); teras.id (Jakarta); acehkita.com (Banda Aceh); kabarmedan.com (Medan); batamnews.co.id (Batam); riauonline.co.id (Pekanbaru); seputarjabar.com (Bandung); timlo.net (Solo); kabarkota.com (Yogyakarta); jurnas.com (Jakarta); potretnews.com (Pekanbaru); kabarmakassar.com (Makassar); kabarnusa.com (Denpasar); beritalingkungan.com (Jakarta), and degorontalo.co (Gorontalo). Such disclosure implies that in producing information, teraslampung takes into account the news syndication as its partners in developing news narratives.

From the results, we found that technological disruption has encouraged newsrooms and media companies to transform. This disruption reaches the point of ambivalence between journalistic idealism and the political economy of digital journalism. These two key points of dilemma were the basic assumptions of this study. First, the digital media ecosystem 
forces journalism to transform, in the context of both newsrooms and media business models, resulting in a conflicting interest between journalistic idealism and market demands. Second, the movement of digital journalism forces various media companies to make collaborate to survive amid the hustle and bustle of media industry competition. This then becomes the contradiction between social responsibility and the political economy practice of media.

\section{Between Idealism and Market Demand}

Through the elaboration of relations and collaboration among various digital media platforms in Indonesia, we can see that the first assumption of this study was answered. Journalism has transformed, in the context of both newsrooms and business management of digital media. Some media could survive even though they still uphold their journalistic idealism, but some others have to make innovations by transforming according to what the market wants. Holding Company usually prefers to transform to meet what the market wants by sorting and selecting contents in specific contexts. The variety of digital media managed by EMTEK offers a variety of contents with specific topics. For examples, general news content on Liputan6.com, soccer on Bola.com, young generation and lifestyle on Brilio.net, Islamic contents on Dream.co.id, as well as entertainment and celebrities on Bola.com. The same pattern is performed by Kompas Gramedia to its digital media platforms.

Different patterns are used by JPNN and Tribune. The two corporate networks do not choose thematic segmentation for their media, but region-based segmentation. Both Tribune and JPNN develop networks with local media in the regions to broadcast information that is not national-centred. These two patterns are usually chosen by holding companies that are usually stable national media which start from print media. That is, digital media serve as a supporting system and a form of spatialization performed by media companies. The digital media in large media companies usually serve as product differentiation, instead of a form of the diversity of contents. On the Alexa index (December 2018), Tribunnews ranked the second most frequently accessed website in Indonesia, while Jawa Pos ranked the 46th. This indicates that the pages of both media are quite often accessed by the public when searching for information.

From the perspective of management, the presence of digital media platforms serves as the driver of the company to earn profits. On the other hand, the massive development of digital company could be the entrance of uniform information, particularly related to the ideological position of the company. This means that the diversity of content will still contradict the ideological position of the company. The same phenomenon is also found in media companies with news syndication. Syndication in digital journalism is intended not only to keep media contents existing but also to provide contents that contain more general discourses for the public. Trending topic certainly still becomes a reference for digital journalism platforms in performing their journalism activities and organizational management activities. The following general discourses could increase the accessibility index of the media. Another basic principle for news syndication practice is when users share information from the news (Zubiaga et al., 2011). This activity involves some keywords to allow for easy searches and reproduction. This practice is also the beginning of the hegemony spreading through the media. 
"Syndication involves the sale of the same good to many customers" (Werbach, 2000), which is then reproduced and redistributed. Seemingly uniform information posted by news syndication is caused by uniform and repetitive sources. This practice tends to be seen as a business method for disseminating information, instead of upholding journalistic idealism. Instead of creating proper contents on the media, news syndication tends to flood the public space with uniform information. This is certainly far from a diversity of contents that should be upheld in journalism.

The diversity of media contents in digital journalism ideally emerges along with the diversity of ownership. Even so, networking carried out by both large media companies and local media networks in news syndication obscures the concept. It is structurally important to realize that the gatekeeping position in digital journalism has been disrupted by a media hierarchy that is no longer dominant. The processes of selection and representation in digital journalism are not only about formal structures (Shoemaker \& Reese, 2014; Schudson, 2001). The decision to disseminate news to the public involves not only humans but also data and machines. The public has become a consideration for the media whether to publish or not to publish particular news because the public becomes a gate watching in journalism processes. This means that whatever is done by the public will be a consideration for the media because the media revenue comes from the public.

\section{The ambivalence of Responsibilities and Political Economy Practices}

The second assumption of this study is the ambivalence between journalism responsibilities and political economy practices as an effort of media companies to survive. Digitization allows for everyone to carry out journalism activities. Technological disruption has caused journalism to transform and this, fundamentally, has allowed journalism to appear anywhere. Anderson $(2012$, p.76) stated that the "journalism industry is dead, but journalism exists in many places." Anyone can develop narrations and this has become the most difficult challenge from the development of digital journalism.

Technological disruption has encouraged quite a several new genres in journalism to emerge, indicating the development of media contents and texts. The power of netizens with citizen journalism is manifested in the practices of Facebook journalism and other social media journalism. Also, social media has now transformed into a resource for journalists to build media texts (Broersma \& Graham, 2012; Hamzah \& Esa, 2020). In this context, journalists no longer need to conduct detailed data gathering in the field because social media is considered a representation of individual informants in journalism. Nevertheless, such practice also raises a dilemma related to the validity of the informants. Instead of providing verified information to the public, such type of journalism has led to the manipulation of news sources because the social media accounts being used are not always the real account of the informants.

The positive side of using big data to develop digital journalism genres is the formation of data journalism and fact-checking journalism. Fact-checking journalism is a journalism practice carried out by Tirto with Facebook in verifying hoax circulating among a community. In verifying news, Tirto not only develops news narratives but also attaches hyperlinks that could be accessed by the public. The media serves as an educator and storyteller, while the community serves as the gate watching. This journalism genre has received appreciation because it is a manifestation of the war against hoaxes, which significantly positions the media following its professional responsibilities and journalism functions. 
The dilemmatic aspect that emerged along with the development of fact-checking journalism and data journalism is related to data ownership. Data verification and narration processes that involve data make use of algorithms based on the distribution of data in digital platforms. Similar to technology, the data in digital platforms are neutral, depending on the persons that process and narrate it. As revealed by Anderson (2012), "journalism exists in many places," including in places where data and technology can be processed and used by those who do not work as "pure journalists". This phenomenon can be found in Ayo Media Network. The media platforms developing from this network were not entirely established as a journalism product because Ayo Media Network was not a media organization. This network is an agency that initiates the development of digital platforms. This way, their services are not only related to ethical and professional journalism practices but rather about the ecosystem to build the digital journalistic habitus. Journalism practice is more likely to be defined as the utilization of digital media that brings economic benefits rather than upholding journalism responsibilities to the public.

The contradiction between social responsibility and political-economic practices that can be found in digital journalism provides an answer to the concern of the media industry which is indeed unbalanced. The digital media industry develops along with the growth of free contents on various digital media platforms amid the inability of the news business to generate a decent income from the online activities they are engaged in (Herbert $\&$ Thurman, 2007; Chyi, 2005; Casero-Ripolles \& Izquierdo-Castillo, 2013). All the lines of media that operate as digital journalism transform to survive amid competition. At the same time, content providers emerge. They become a determinant even though they do not participate in the competition. This indicates that the growth of digital journalism does not always show a positive trend because what emerges is content providers, instead of media that are responsible for any contents they professionally provide. This means that nowadays innovation is an aspect needed by digital media to win the competition among digital platforms that keep emerging.

Content providers can emerge at any time, yet digital journalism responsible for making innovations does not emerge every day. Journalists and media companies must consider the social responsibility factor as the key point of journalism practices, rather than going with the political economy flow of media that can destroy media companies at any time. There is always supply and demand in the market because economic activities start from such things. In addition to the diversity of content and diversity of ownership, the digital journalism ecosystem also needs the diversity of product which can allow for the digital journalism platform to survive from the disruption of information technology. Collaboration of media organizations to produce digital journalism products brings positive implications if properly developed.

\section{CONCLUSIONS}

Communication technology has disrupted journalism with several genres that emerge in digital journalism. When people tend to have the needs of being faster, more practical, more involved, and more engaged in interaction, digital media should make journalism easier, faster, and more accurate. However, during the high market demand, journalism must always be able to choose between upholding journalistic idealism or contradicting political economy. 
Ideally, journalism practice always adheres to the initial functions of professional journalism, i.e. encouraging democratization in making use of media through the diversity of content and diversity of ownership. Digital journalism has made such diversity exist on another line, namely diversity of products. The diversity of digital products arises from the relations and innovations developed by the digital journalism network. Digital news as a product of digital journalism is the result of disruption of collaboration among various media companies to survive and maintain their existence in the digital media ecosystem. This is what Pavlik (2001) defined as the transformation undergone by journalism when dealing with technology. Eventually, collaboration and disruption of media companies are not only a mere consequence but also a digital media strategy in serving the community and carrying out their normative roles.

\section{BIODATA}

Mufti Nurlatifah is a Doctoral Student at the Doctoral Programme, Department of Communication, Universitas Indonesia. Her research is focused on journalism and media law. Email: mufti.latifah@gmail.com

Nina Mutmainnah is a Lecturer and the Head of the Department of Communication, Universitas Indonesia. The focus of her research related to broadcasting, media policy, and media literacy. She is quite active in the nationals forum in Indonesia, particularly in the field of broadcasting and communication policy. Email: n.mutmainah@ui.ac.id 


\section{REFERENCES}

Alassuutari, P., Bickman, L., \& Brannen, J. (Ed.). (2008). The Sage handbook of social research methods. Sage Publications.

Amazeen, M. A. (2017). Journalistic interventions: The structural factors affecting the global emergence of fact-checking. Journalism, 21(1), 95-111. https://doi.org/gf8pn8

Anderson, C. W. (2013). Rebuilding the news: Metropolitan journalism in the digital age. Temple University Press.

Anderson, C. W., Bell, E., \& Shirky, C. (2012). Post-industrial Journalism: Adapting to the present. The Tow Center for Digital Journalism. https://towcenter.columbia.edu/n/

Anthony, S. D. (2012). The little black book of innovation: How it works, how to do it. Harvard Business Review Press.

Besser, H. (1995). From the internet to information superhighway. In Brook, J. B. (Ed.), Resisting the virtual life: The culture and politics of information. City Lights.

Biagi, S. (2016). Media impact: An introduction to mass media. Cengage Learning.

Boczkowski, P. J. (2004). Digitizing the News: Innovation in online newspapers. The MIT Press.

Bolter, D. J., \& Grusin, R. (1999). Remediation: Understanding new media. The MIT Press.

Broersma, M., \& Graham, T. (2012). Social media as a beat: Tweets as a news source during the 2010 British and Dutch elections. Journalism Practice, 6(3), 403-419.

Bruns, A. (2004). Reconfiguring journalism: Syndication, gate watch, and multiperspective news. In Goggin, G. (Ed.), Virtual Nation: The internet in Australia. University of New South Wales Press.

Bustamante, E. (2004). Cultural industries in the digital age: Some provisional conclusions. Media, Culture \& Society, 26(6), 803-820. https://doi.org/fkfwqk

Casero-Ripolles, A., \& Izquierdo-Castillo, J. (2013). Between decline and a new online business model: The case of the Spanish newspaper industry. Journal of Media Business Studies, 10(1), 63-78. https://doi.org/10.1080/16522354.2013.11073560

Chyi, H. I. (2005). Willingness to pay for online news: An empirical study on the viability of the subscription model. Journal of Media Economics, 18(2), 131-142. https://doi.org/10.1207/s15327736me1802 4

Deuze, M., \& Witschge, T. (2018). Beyond journalism: Theorizing the transformation of journalism. Journalism, 19(2), 165-181. https://doi.org/10.1177/1464884916688550

Evens, T., Raats, T., \& Rimscha, M. B.. (2017). Business model innovation in news media organisations: 2018 special issue of the European media management association. Journal of Media Business Studies, 14(3), 167-172. https://doi.org/gfn44w

Gibbs, G. R. (2007). Analysing qualitative data. Sage Publications.

Golding, P. (1996). World wide wedge: Division and contradiction in the global information infrastructure. Monthly Review, 48(3), 70. https://doi.org/f2m2

Hamzah, M., \& Esa, I. L. (2020). Uncovering the factors influencing the technological adaptation of Twitter usage among journalists in the transforming journalism practice. Jurnal Komunikasi: Malaysian Journal of Communication, 36(4), 1-15.

Herbert, J., \& Thurman, N. (2007). Paid content strategies for news websites. Journalism Practice, 1(2), 208-226. https://doi.org/10.1080/17512780701275523

Hermida, A. (2013). \#Journalism: Reconfiguring journalism research about Twitter, one tweet at a time. Digital Journalism, 1(3), 295-313. https://doi.org/ggb566

Kawamoto, K. (Ed.). (2003). Digital journalism: Emerging media and the changing horizons of journalism. Rowman and Littlefield Publishers. 
Lindgren, S. (2017). Digital media and society. Sage Publications.

Pavlik, J. V. (2008). Media in the digital age. New York: Columbia University Press.

Maryani, E., Rahmawan, D., \& Karlinah, S. (2020). The implications of social media on local media business: Case studies Palembang, Manado, and Bandung. Jurnal Komunikasi: Malaysian Journal of Communication, 36(1), 317-333. https://doi.org/ $\$ 2 \mathrm{m3}$

McChesney, R. W., \& Nichols, J. (2010). The death and life of American journalism: The media revolution that will begin the world again. Nation Books.

Mosco, V. (2009). The political economy of communication (2nd ed.). Sage Publications.

Murdock, G., \& Golding, P. (2002). Digital possibilities, market realities: The contradictions of communications convergence. Socialist Register 2002: A World of Contradictions, 38. https://socialistregister.com/index.php/srv/article/view/5779

Negroponte, N. (1996). Being digital. Coronet Books.

Norris, P. (2001). Digital divide: Civic engagement, information poverty, and the internet worldwide. Cambridge University Press.

Omar, B. (2017). Online news production, consumption, and immediacy: The remediation perspective. Jurnal Komunikasi: Malaysian Journal of Communication, 33(3), 250-266.

Schudson, M. (2003). The sociology of news. W.W. Norton and Company.

Shoemaker, P. J., \& Reese, S. D. (2014). Mediating the message in the 21st century: A media sociology perspective. Routledge.

Sloan, L., \& Quan-Haase, A. (2017). The Sage handbook of social media research methods. Sage Publications.

Tapsell, R. (2015). Platform convergence in Indonesia: Challenges and opportunities for media freedom. Convergence, 21(2), 182-197. https://doi.org/10.1177/1354856514531527

Tameling, K., \& Broersma, M. (2013). De-converging the newsroom: Strategies for newsroom change and their influence on journalism practice. International Communication Gazette, 75(1), 19-34. https://doi.org/10.1177/1748048512461760

Werbach, K. (2000, May-June). Syndication: The emerging model for business in the internet era. Harvard Business Review, 78, 84-93. https://hbr.org/2000/05/syndication-theemerging-model-for-business-in-the-internet-era

Wikstrom, P., \& Ellonen, H. K. (2012). The impact of social media features on print media firms online business models. Journal of Media Business Studies, 9(3), 63-80.

Wimmer, R. D., \& Dominick, J. R. (2010). Mass media research: An introduction. Wadsworth, Cengage Learning.

Wunsch-Vincent, S. (2017). Online news: Recent developments, new business models, and prospects. In Levy, D. A., \& Nielsen, R. K. (Eds.), The changing business of journalism and its implications for democracy. Reuters Institute for the Study of Journalism.

Yusuf, N. Q. (2009). Jejak-jejak makna basrizal koto: Dari titik nol menjadi enterpreneur mulia. Kompas Gramedia Building.

Zubiaga, A., Spina D., Fresno-Fernandez, V., \& Martinez-Unanue, R. (2011). Classifying trending topics: A typology of conversation triggers on Twitter. International Conference on Information and Knowledge Management Proceedings, CIKM 11, 24612464. https://doi.org/10.1145/2063576.2063992 